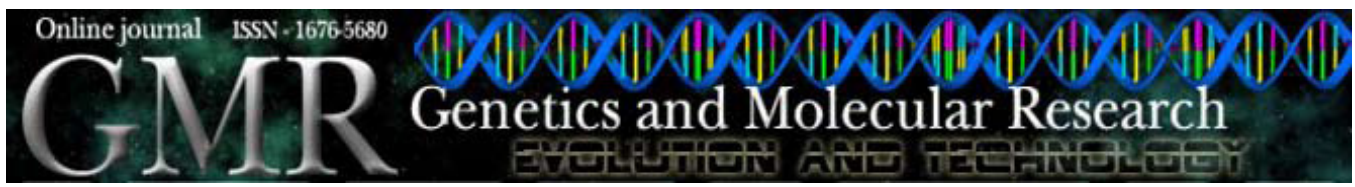

\title{
Chromosomal diversity and phylogenetic inferences concerning thrips (Insecta, Thysanoptera) in a semi-arid region of Brazil
}

\author{
R.O. Brito, P.R.A.M. Affonso and J.C. Silva Jr. \\ Laboratório de Citogenética, \\ Departamento de Ciências Biológicas, \\ Universidade Estadual do Sudoeste da Bahia, Jequié, BA, Brasil \\ Corresponding author: J.C. Silva Jr. \\ E-mail: juvenaljr@yahoo.com.br
}

Genet. Mol. Res. 9 (4): 2230-2238 (2010)

Received May 8, 2010

Accepted July 9, 2010

Published November 16, 2010

DOI 10.4238/vol9-4gmr843

\begin{abstract}
The order Thysanoptera is composed of cosmopolitan phytophagous and predaceous insects with diverse life histories, behaviors and habits. This order is currently thought to form a trichotomy with Hemiptera and Psocodea; Hemiptera and Thysanoptera are considered to be sister groups. The interrelationships within Thysanoptera remain unclear and cytotaxonomic studies are scarce in thrips. We report, for the first time, chromosomal data on seven species of thrips collected from a semi-arid region in the States of Bahia and Pernambuco (Northeast Brazil). A distinctive chromosomal pattern was observed in Thysanoptera when compared to other members within the infraclass Paraneoptera. Considerable karyotypic differences were also found within genera and species of Thysanoptera. Based on these data, we suggest that Paraneoptera forms a polyphyletic group and that Terebrantia and Tubulifera should be regarded as sister groups. The high chromosomal variability observed in Thysanoptera indicates that chromosomal rearrangements have played a key role in their speciation pathways.
\end{abstract}

Key words: Cytotaxonomy; Chromosomal evolution; Thysanoptera; Paraneoptera 


\section{INTRODUCTION}

The order Thysanoptera mainly comprises phytophagous and tiny insects ( 0.5 to 15 $\mathrm{mm}$ in length) of elongated body that feed on fungi and leaves, which are popularly known as thrips (Mound and Marullo, 1996; Mound, 2005). They are cosmopolitan and show distinct behaviors and life histories, ranging from solitary to subsocial to eusocial forms (Mound and Kibby, 1998; Chapman et al., 2000; Kumm, 2002).

The thrips comprise a monophyletic group easily recognized by the winged adult form, which has narrow wings, with reduced venation and a fringed border (Grimaldi et al., 2004). According to Moritz et al. (2001), the order Thysanoptera is composed of nine families, eight of them belonging to the suborder Terebrantia (Uzelothripidae, Merothripidae, Aeolothripidae, Melanthripidae, Adiheterothripidae, Fauriellidae, Heterothripidae, and Thripidae) and a single family (Phlaeothripidae) in the suborder Tubulifera.

It is currently thought that Thysanoptera is part of an unresolved trichotomy with Hemiptera and Psocodea (Psocoptera + Phthiraptera) (Kristensen, 1991). However, Yoshizawa and Saigusa (2001) suggested that Hemiptera and Thysanoptera could be referred to as sister groups, and, together, they would comprise a sister group to Psocodea.

The relationships within the order Thysanoptera also remain unclear. The families in the suborder Terebrantia show a more or less progressive series of plesiomorphic forms coupled with derived traits, whereas the members of the single family in Tubulifera lack any plesiomorphic character (Mound and Morris, 2004). Recent molecular data derived from $18 \mathrm{~S}$ rDNA analysis support some aspects of the existing classification, but far more resolution is still required (Mound and Morris, 2007).

Cytogenetic studies in thrips are scarce. So far, only the chromosome number of no more than 10 species is available (Risler and Kempter, 1961). In the present study, we report, for the first time, the cytogenetic data for seven species of Thysanoptera in order to provide inferences about the relationships within this insect group.

\section{MATERIAL AND METHODS}

Seven species of Thysanoptera from both suborders were analyzed. Immature individuals were used to obtain mitotic chromosomes. They were collected from crops and ornamental plants or flowers in several cities in the States of Bahia and Pernambuco (Northeast Brazil) (Table 1, Figure 1).

Metaphase chromosomes were obtained following the technique described by Imai et al. (1988), using the ganglia of immature animals. The anterior portions of the 2nd-instar

\begin{tabular}{llll}
\multicolumn{2}{l}{ Table 1. Species of thrips studied. } \\
\hline Suborder & Family & Species & Collection site (city, state, host plant) \\
\hline Terebrantia & Thripidae & Selenothrips rubrocinctus (Giard, 1901) & Salvador (BA), Terminalia catappa \\
& & Retithrips syriacus (Mayet, 1890) & Pertolina (PE), Vitris vinifera \\
& Frankliniella schultzei (Trybom, 1910) & Maracás (BA), Gladiolus sp \\
& Frankliniella insularis (Franklin, 1908) & Jequié (BA), Musa paradisiaca \\
Tubulifera & Phlaeothripidae & Gynaikothrips uzeli (Zimmerman, 1900) & Jequié (BA), Jaguaquara (BA), Ficus benjamina \\
& & Gynaikothrips ficorum (Marshal, 1908) & Jequié (BA), Ficus retusa \\
& & Liothrips sp (Uzel, 1895) & Jequié (BA), Psidium guajava \\
\hline
\end{tabular}



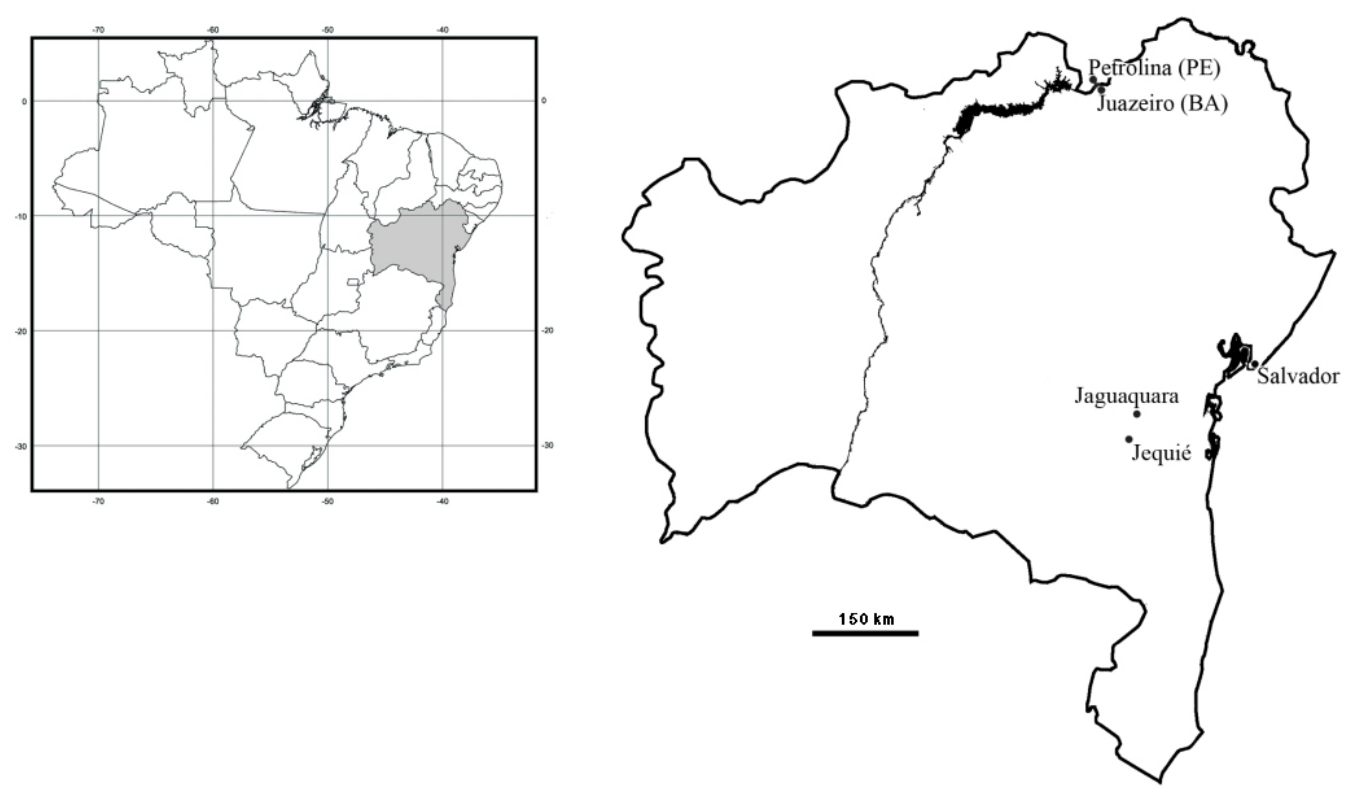

Figure 1. Map of Bahia State, Brazil, showing the collection sites.

larvae (head and the 1st thoracical segment), prior to fixation, were immersed in hypotonic colchicine-citrate solution $(0.1 \%)$, for a variable time according to each species.

A minimum of five metaphases per slide of 35 individuals of each species were analyzed. The chromosomal morphology was determined according to Levan et al. (1964), based on centromere position $(\mathrm{M}=$ metacentric; $\mathrm{Sm}=$ submetacentric; $\mathrm{A}=$ acrocentric, and $\mathrm{T}=$ telocentric). The best metaphases (100X enlarged) were photographed under a Leica DMLS light microscope using Imagelink ISO 25 (Kodak) film for karyotype arrangement.

\section{RESULTS}

\section{Suborder Terebrantia - Family Thripidae}

Selenothrips rubrocinctus displayed a symmetric karyotype with $2 \mathrm{n}=36$ small chromosomes for females and $\mathrm{n}=18$ for males (Figure $2 \mathrm{~A}$ and $\mathrm{B}$, respectively). The karyotype formula is $2 \mathrm{n}=6 \mathrm{M}+22 \mathrm{Sm}+8 \mathrm{~A}$.

Frankliniella schultzei showed a complement of $2 \mathrm{n}=34$ for females and $\mathrm{n}=17$ for males (Figure $2 \mathrm{C}$ and $\mathrm{D}$, respectively). The karyotype is bimodal with 16 small submetacentric chromosome pairs and a single large acrocentric pair $(2 \mathrm{n}=32 \mathrm{Sm}+2 \mathrm{~A})$.

Retithrips syriacus showed $2 \mathrm{n}=38$ for females. Male individuals had not been sampled. The diploid karyotype formula is $2 \mathrm{n}=12 \mathrm{M}+16 \mathrm{~A}+10 \mathrm{~T}$ (Figure 2E).

Frankliniella insularis showed a chromosome number of $2 \mathrm{n}=28$ for the individuals analyzed (all females). The karyotype formula in this species could not be precisely defined (Figure 2F). 
A

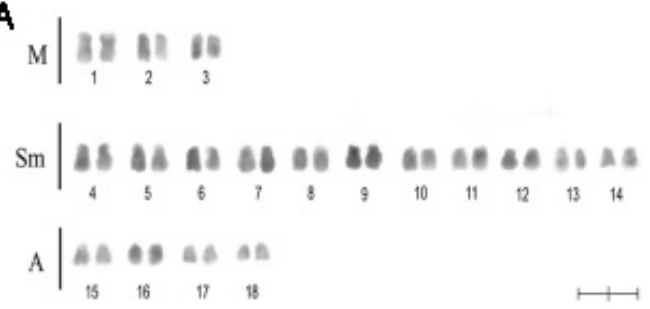

C
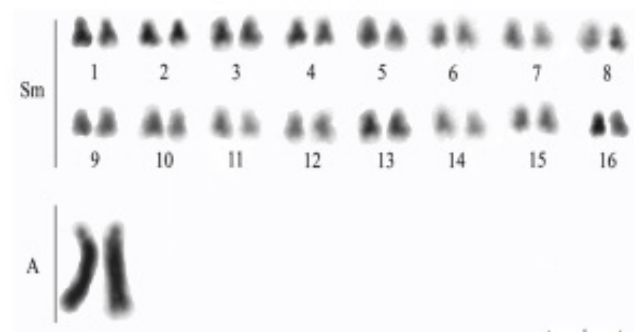

17

E

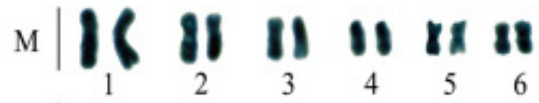

A
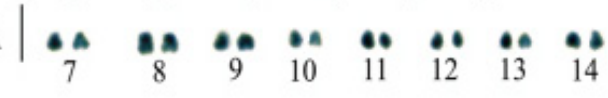

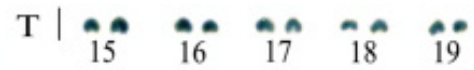

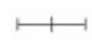

\section{日}

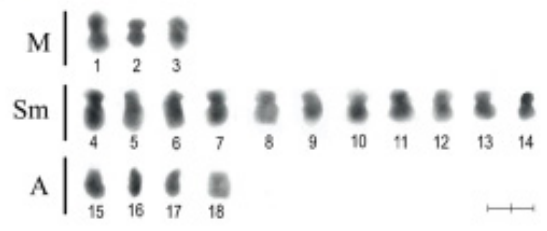

D

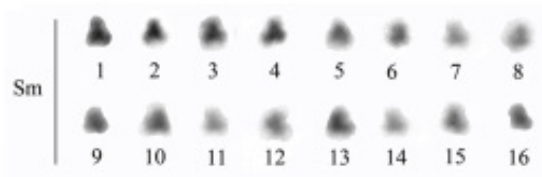

A

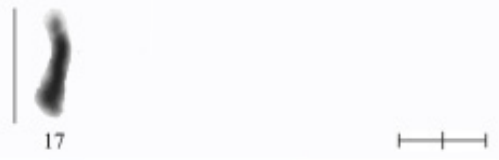

$\mathbf{F}$

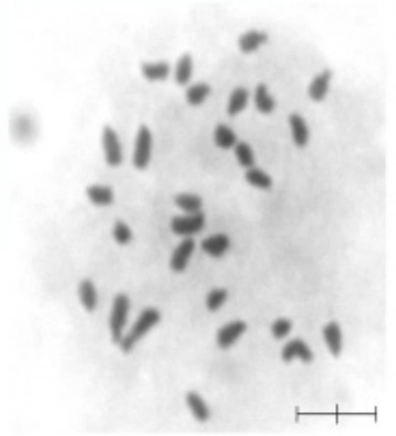

Figure 2. Karyotype of species of Thripidae studied and mitotic metaphase of Frankliniella insularis. A. Selenothrips rubrocinctus (female); B. S. rubrocinctus (male); C. F. schultzei (female); D. F. schultzei (male); E. Retithrips syriacus (female); F. F. insularis. $\mathrm{M}=$ metacentric; $\mathrm{Sm}=$ submetacentric; $\mathrm{A}=$ acrocentric; $\mathrm{T}=$ telocentric. Bar $=5 \mu \mathrm{m}$.

\section{Suborder Tubulifera - Family Phlaeothripidae}

Liothrips sp showed $2 \mathrm{n}=24$ for females and $\mathrm{n}=12$ for males. The diploid karyotype is symmetric, with a formula of $2 \mathrm{n}=12 \mathrm{M}+8 \mathrm{Sm}+4 \mathrm{~A}$ (Figure $3 \mathrm{~A}$ and $\mathrm{B}$ ). The 11 th chromosome pair commonly showed secondary constrictions.

Two cytotypes were found in Gynaikothrips uzeli, so-called A and B, regarding two distinct localities in the State of Bahia; Jequié and Jaguaquara, respectively. In cytotype A, the chromosome number is $2 n=26$ for females and $n=13$ for males (Figure $3 \mathrm{C}$ and D). The 
A

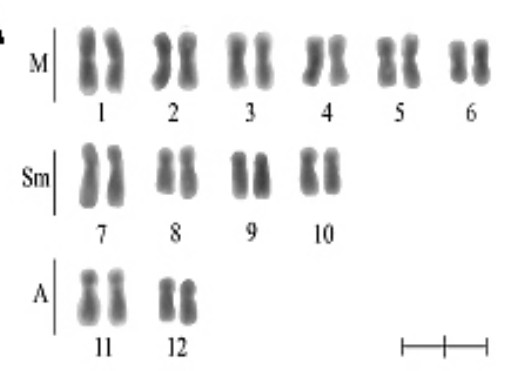

C

a) $88 x 413 x$

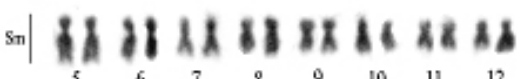

A) it

E

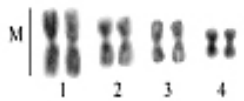

$\operatorname{sm} \mid \begin{array}{ll}5 \\ 5\end{array}$

$A \mid \mathbf{d}$

G

M)

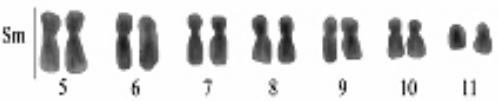

A $\mid$

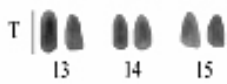

日

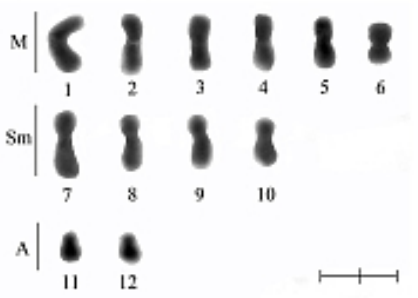

$D_{M} 1: 1:$

$\begin{array}{lllllllll}\mathrm{Sm} & \mathbf{3} & \mathbf{3} & \mathbf{8} & \mathbf{8} & \mathbf{3} & \mathbf{4} & \mathbf{8} & \mathbf{8}\end{array}$

A $\mathbf{~}$

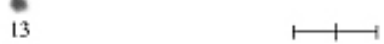

F

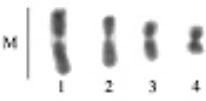

$\operatorname{sm} \mid$\begin{tabular}{llllllllll}
$\mathbf{1}$ & $\mathbf{1}$ & $\mathbf{1}$ & $\mathbf{1}$ & $\mathbf{1}$ & $\mathbf{7}$ & $\mathbf{1}$ & $\mathbf{1}$ & $\mathbf{8}$ \\
\hline & 7 & 8 & 9 & 10 & 11 & 12 & 13 & 14
\end{tabular}

$\therefore \mid$

Figure 3. Karyotype of species of Phlaeothripidae studied. A. Liothrips sp (female); B. Liothrips sp (male); C. Gynaikothrips uzeli, cytotype A (female); D. G. uzeli, cytotype A (male); E. G. uzeli, cytotype B (female); F. G. uzeli, cytotype B (male); G. G. ficorum (female). M = metacentric; Sm = submetacentric; A $=$ acrocentric; $\mathrm{T}=$ telocentric. $\mathrm{Bar}=5 \mu \mathrm{m}$.

karyotype is symmetric with a formula of $2 \mathrm{n}=8 \mathrm{M}+16 \mathrm{Sm}+2 \mathrm{~A}$. The 13th chromosome pair commonly showed secondary constrictions.

The chromosome number in cytotype $B$ is $2 n=30$ chromosomes for females and $n=15$ for males (Figure 3E and F). The karyotype is composed of four metacentric pairs, the first being 
larger than the others, plus ten pairs of submetacentric chromosomes, comprising a larger pair, nine pairs of similar size and a single pair of acrocentric chromosomes $(2 \mathrm{n}=8 \mathrm{M}+20 \mathrm{Sm}+2 \mathrm{~A})$.

Gynaikothrips ficorum revealed a chromosome complement of $2 \mathrm{n}=30$ for females (Figure $3 \mathrm{G}$ ). The karyotype is symmetric with a formula of $2 \mathrm{n}=8 \mathrm{M}+14 \mathrm{Sm}+2 \mathrm{~A}+6 \mathrm{~T}$. Males were not analyzed.

\section{DISCUSSION}

To date, cytogenetic data are available for 17 species of thrips, including the present results (Table 2). This number represents less than $0.5 \%$ of the Thysanoptera species described so far.

\begin{tabular}{|c|c|c|}
\hline Taxon & $\mathrm{n}$ & Reference \\
\hline \multicolumn{3}{|l|}{ Tubulifera } \\
\hline \multicolumn{3}{|l|}{ Phlaeothripidae } \\
\hline Gynaikothrips ficorum & $\mathrm{n}=15$ & Present study \\
\hline Gynaikothrips uzeli & $\mathrm{n}=13 / 15$ & Present study \\
\hline Liothrips sp & $\mathrm{n}=12$ & Present study \\
\hline Haplothrips tritici & $\mathrm{n}=10$ & Bournier (1956) \\
\hline Haplothrips statices & $\mathrm{n}=15$ & Risler and Kempter (1961) \\
\hline Neoheegeri verbasci & $\mathrm{n}=12$ & Bournier (1956) \\
\hline \multicolumn{3}{|l|}{ Terebrantia } \\
\hline \multicolumn{3}{|l|}{ Thripidae } \\
\hline Aptinothrips rutua & $\mathrm{n}=50 / 53$ & Prussard-Radulesco (1930) \\
\hline Frankliniella schultzei & $\mathrm{n}=17$ & Present study \\
\hline Frankliniella insularis & $\mathrm{n}=14$ & Present study \\
\hline Heliothrips haemorrhoidalis & $\mathrm{n}=16$ & Pomeyrol (1929) \\
\hline Heliothrips haemorrhoidalis & $\mathrm{n}=26 / 28$ & Prussard-Radulesco (1930) \\
\hline Heliothrips haemorhroidalis & $\mathrm{n}=21$ & Bournier (1956) \\
\hline Limothrips dentricornis & $\mathrm{n}=19$ & Bournier (1956) \\
\hline Parthenothrips dracaenae & $\mathrm{n}=15$ & Prussard-Radulesco (1930) \\
\hline Retithrips syriacus & $\mathrm{n}=19$ & Present study \\
\hline Selenothrips rubrocinctus & $\mathrm{n}=18$ & Present study \\
\hline Sericothrips staphilinua & $\mathrm{n}=14$ & Bournier (1956) \\
\hline Taeniothrips iconsequene & $\mathrm{n}=18 / 20$ & Prussard-Radulesco (1930) \\
\hline Taeniothrips iconsequene & $\mathrm{n}=16$ & Prussard-Radulesco (1930) \\
\hline Taeniothrips simplex & $\mathrm{n}=10$ & Bournier (1956) \\
\hline
\end{tabular}

Based on morphological traits, Thysanoptera is thought to be closely related to the orders Hemiptera, Psocoptera and Phthiraptera, comprising the infraclass Paraneoptera (Kristensen, 1991). However, from a cytogenetic point of view, these groups are quite distinguishable. Hemipterans, Psocoptera and Phthiraptera are characterized by the presence of holocentric chromosomes and sex chromosome systems (Tombesi et al., 1999; Golub et al., 2004; Golub and Nokkala, 2004; Rebagliati et al., 2005).

On the other hand, all thysanopterans evaluated so far show monocentric chromosomes and lack visible sex chromosomes. Moreover, it should be pointed out that arrhenotokous parthenogenesis is observed among thysanopterans.

Such chromosomal differentiation, coupled with some morphological features, suggest that the orders from the infraclass Paraneoptera comprise a polyphyletic group. These results reinforce the necessity of a major review about the phylogenetic position of Thysanoptera within hemipteroids.

The relationships between both Thysanoptera suborders are also controversial as demonstrated by morphological and molecular studies (Mound and Morris, 2007). Bhatti (1994) 
proposed that Thysanoptera should be regarded as a superorder, while Terebrantia and Tubulifera would actually reach an order status. However, this suggestion has been refuted by some authors, since the synapomorphies present in the buccal apparatus and tarsum would represent strong evidence of a single evolutionary lineage (Mound and Morris, 2004). Moreover, Mound et al. (1980) proposed two hypotheses about the interrelationships between the two suborders: Terebrantia and Tubulifera would be sister groups or else Tubulifera would be a sister group of the family Thripidae within Terebrantia. A data set based on nearly $600 \mathrm{bp}$ of $18 \mathrm{~S}$ rDNA from 52 Thysanoptera, representing seven of nine families, although producing a first good approximation of thysanopteran phylogeny, was not sufficiently robust to test the hypothesis of relationships within the order (Morris and Mound, 2003; Mound and Morris, 2007).

The available cytogenetic reports show that Terebrantia species usually display higher chromosome numbers than Tubulifera. The haploid chromosome number in Tubulifera species ranges from 10 to 15 , while four distinct chromosome numbers are reported in a single species of Terebrantia, Heliothrips haemorrhoidalis (see Table 2). A remarkably high $\mathrm{n}$ value (53 chromosomes) was reported in Aptinothrips rutua (Prussard-Radulesco, 1930), although such unusual result can be related to methodological constraints of that time and/or to the tissue/organ used in the cytogenetic preparation. Additionally, the Terebrantia representatives showed small-sized chromosomes when compared to Tubulifera. These data indicate that several chromosomal rearrangements seem to have taken place during the karyoevolutionary history of Terebrantia species, mainly driven by centric fissions/fusions.

Therefore, the chromosomal structure reported in Thysanoptera species supports the phylogenetic hypothesis that view Terebrantia and Tubulifera as distinct suborders, since members from both groups show clear chromosomal differences.

The present results are in accordance with the minimum interaction theory proposed by Imai et al. (1986), suggested as a common model of karyotypic evolution for eukaryotes. Based on this theory, the increase in chromosome numbers during the evolutionary process would act as an adaptive mechanism by reducing the risks of deleterious chromosomal recombination within the genome. This process would result in a higher chromosome number coupled with reduction of chromosome size.

Furthermore, the karyotypic studies carried out in thrips show a great variation in both number and morphology of chromosomes, including family, genus and species levels (Table 2). For instance, both species studied in the genus Frankliniella (Terebrantia) revealed numerical and structural chromosomal differences. Remarkably, within Tubulifera, a single species, G. uzeli, displayed variable karyotypes, characterizing two cytotypes, named A and B with $\mathrm{n}=$ 13 and $\mathrm{n}=15$, respectively. The species of the genus Gynaikothrips studied here constitute an interesting material, since they represent a group where there is a true co-evolutionary association with their plant hosts. Mound (1994) suggests that the thrips species associated with Ficus would be the same and that their morphological variation would result from intraspecific variation and G. uzeli and G. ficorum would thereby be synonyms. Thus, these authors proposed that the criterion used to distinguish the two species (the size of posteroangular and epimeral setae) would reflect differences in the hosts and latitude of populations.

Nonetheless, the cytogenetic data support the species status for G. uzeli and G. ficorum, inasmuch as cytotype A of G. uzeli differs from G. ficorum in relation to both chromosome number and morphology, while cytotype B, although sharing a similar chromosome number with G. ficorum, shows differences related to the number of submetacentric chromo- 
somes and to the absence of telocentric types. The similarity between G. ficorum karyotype and cytotype B of G. uzeli indicates the occurrence of pericentric inversions as the main rearrangement. The greater karyotypic resemblance between G. uzeli (cytotype B) and G. ficorum than between the two cytotypes indicates a remarkable level of intraspecific differentiation, possibly related to the environmental features of each cytotype - the samples in Jequié (cytotype A) are under a strict semi-arid climate, whereas Jaguaquara (cytotype B) is characterized by lower temperatures and more humid weather.

Another alternative hypothesis to explain this variation in G. uzeli is that both cytotypes may be derived from cytogenetically distinct populations within their original range in Southeast Asia, including Taiwan, China and India (Ananthakrishnan, 1978; Mound et al., 1995; Mound and Marullo, 1996). In this case, the interpopulation difference would be prior to the introduction of G. uzeli in Brazil.

Although clear morphological differences are absent, the cytogenetic results show that not only may G. ficorum and G. uzeli be regarded as distinct species, but that the variation observed in G. uzeli could putatively represent a species complex as well.

In spite of all advances related to molecular genetics, cytogenetic studies still stand out as an efficient tool for systematic approaches (cytotaxonomy) in several animal groups, where they are helpful in the discrimination of morphologically similar species (cryptic species), since the karyotype itself represents a trait resistant to environmental, behavioral or physiological influences (White, 1973; Sumner, 2003). Therefore, chromosomal alterations are usually significant in the evolutionary process of a species (Gibson, 1984).

The remarkable karyotypic variability observed in thysanopterans could be useful for taxonomic studies in this group, since the phenotypic variation is usually reduced and morphological traits seem to be poorly informative. The cytogenetic data may therefore help us understand the karyotypic evolution and the phylogenetic relationships within this group, whether at the order, suborder or family level. Although reduced, the available data indicate that chromosomal rearrangements such as centric fusion/fissions and inversions have played a major role in the speciation process of this insect group, probably reflecting the distinct life histories of its members. The association between karyotypic changes and species natural history can elucidate important aspects related to the ecology and evolution of social behavior in haplo-diploid species.

Further studies based on more refined techniques and comprising a larger number of families and species may contribute significantly to the comprehension of the mechanisms involved in the karyoevolution, systematics and phylogeny of thysanopterans.

\section{ACKNOWLEDGMENTS}

The authors would like to thank Dr. Silvia Pinent for her assistance with species identification and FAPESB for financial support.

\section{REFERENCES}

Ananthakrishnan TN (1978). Thrips galls and gall thrips. Zool. Surv. India 1: 1-95.

Bhatti JS (1994). Phylogenetic relationships among Thysanoptera (Insecta) with particular reference to the families of the order Tubulifera. Zool. (J. Pure Appl. Zool.) 4: 93-130.

Bournier A (1956). Contribution à l'etude de la parthénogenèse des Thysanoptères et sa cytologie. Arch. Zool. Exp. Gén. 93: 220 -317. 
Chapman TW, Crespi BJ, Kranz BD and Schwarz MP (2000). High relatedness and inbreeding at the origin of eusociality in gall-inducing thrips. Proc. Natl. Acad. Sci. U. S. A. 97: 1648-1650.

Gibson LJ (1984). Chromosomal changes in mammalian speciation: a literature review. Origins 11: 67-89.

Golub N and Nokkala S (2004). Chromosome numbers of two sucking louse species (Insecta, Phthiraptera, Anoplura). Hereditas 141: 94-96.

Golub NV, Nokkala S and Kuznetsova VG (2004). Holocentric chromosomes of psocids (Insecta, Psocoptera) analysed by C-banding, silver impregnation and sequence specific fluorochromes CMA3 and DAPI. Folia Biol. 52: 143-149.

Grimaldi G, Shmakov A and Fraser N (2004). Mesozoic thrips and early evolution of the order Thysanoptera (Insecta). $J$. Paleont. 78: 941-952.

Imai HT, Maruyama T, Gojobori T, Inoye Y, et al. (1986). Theoretical bases for karyotype evolution. 1. The minimuminteraction hypothesis. Am. Nat. 128: 900-920.

Imai HT, Taylor RW, Crosland MW and Crozier RH (1988). Modes of spontaneous chromosomal mutation and karyotype evolution in ants with reference to the minimum interaction hypothesis. Jpn. J. Genet. 63: 159-185.

Kristensen NP (1991). Phylogeny of Extant Hexapodas. In: The Insects of Australia. Text Book for Students and Research Workers. 2nd edn. (CSIRO Division of Entomology, ed.). University Press, Melbourne, 125-140.

Kumm FS (2002). Reproduction, Progenesis, and Embryogenesis of Thrips (Thysanoptera, Insecta). Master's thesis, Martin-Luther University, Halle.

Levan AK, Fredga K and Sandberg AA (1964). Nomenclature for centromeric position on chomosomes. Hereditas 52: 201-220.

Moritz G, Morris DC and Mound LA (2001). Thrips ID Pest of the World. An Interactive Identification and Information System. CD-Rom. CSIRO Publishing, Melbourne.

Morris DC and Mound LA (2003). Thysanoptera phylogeny - the molecular future. Entomol. Abh. 61: 153-155.

Mound LA (1994). Thrips and Gall Induction: a Search for Patterns. In: Plant Galls: Organisms, Interactions, Populations (Williams MAJ, ed.). Clarendon Press, Oxford, 131-149.

Mound LA (2005). Thysanoptera: diversity and interactions. Annu. Rev. Entomol. 50: 247-269.

Mound LA and Marullo R (1996). The thrips of Central and South America: an introduction. Mem. Entomol. Int. 6: 1-488.

Mound LA and Kibby G (1998). Thysanoptera: an Identification Guide. 2nd edn. CAB International, Wallingford.

Mound LA and Morris DC (2004). Thysanoptera phylogeny - the morphological background. Acta Phytopathol. Entomol. Hung. 39: 101-113.

Mound LA and Morris DC (2007). The insect order Thysanoptera: classification versus systematics. Zootaxa 1668: 395-411.

Mound LA, Heming BS and Palmer JM (1980). Phylogenetic relationships between the families of recent Thysanoptera. Zool. J. Linnean Soc. 69: 111-141.

Mound LA, Wang CL and Okajima S (1995). Observations in Taiwan on the identity of the Cuban laurel thrips (Thysanoptera, Phlaeothripidae). J. New York Entomol. Soc. 103: 185-190.

Pomeyrol R (1929). La parthénogenèse dês thysanoptères. Bull. Biol. Fr. Belg. 62: 3-12.

Prussard-Radulesco E (1930). Recherches biologiques et cytologiques sur quelques thysanoptères. Ann. Epiphyties 16: 103-188.

Rebagliati PJ, Mola LM, Papeschi AG and Grazia J (2005). Cytogenetic studies in Pentatomidae (Heteroptera): a review. J. Zoolog. Syst. Evol. Res. 43: 199-213.

Risler H and Kempter E (1961). Haploids of males and endopolypoids in some tissues of Haplothrips (Thysanoptera). Chromosoma 12: 351-361.

Sumner AT (2003). Chromosomes: Organization and Function. 1st edn. Blackwell Publishing Co., Oxford.

Tombesi ML, Papeschi AG and Mola LM (1999). Spermatogenesis in Bovicola limbata Gervais, 1844 and B. caprae Gurlt, 1843 (Phthiraptera, Ischnocera). Cytologia 64: 25-27.

White MJD (1973). Cytology and Evolution. 1st edn. Cambridge University Press, London.

Yoshizawa K and Saigusa T (2001). Phylogenetic analysis of paraneopteran orders (Insecta: Neoptera) based on forewing base structure, with comments on monophyly of Auchenorrhyncha (Hemiptera). Syst. Entomol. 26: 1-13. 